\title{
Applying Conversation Method and Self-Confidence and Its Effect to Learning Achievement
}

\author{
${ }^{1}$ Imam Kholis Sagita ${ }^{\bowtie}$, \\ ${ }^{1}$ STIT NU Sumber Agung, OKU Timur, Indonesia

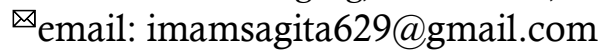

Received:

5 September

2021

Revised:

10 September

2021

Accepted:

10 September

2021

Published:

26 September

2021

\begin{abstract}
English in elementary schools in the implementation of learning is still not effective until now. Actually, there are many problems related to the implementation of the development of English learning. In fact, the development of learning English itself is very beneficial for elementary school students, so they can improve their abilities. The research method used in this classroom action research is an experimental method with a Factorial Group Design (FGD) design with 2 categories. The data analysis technique in this study used two way ANOVA, with the help of computers, namely: SPSS for Windows version 24 program. The results of the study can be concluded that there are differences in English learning outcomes between learning by conversation methods and conventional methods for grade 4 students. Madrasah Ibtidaiyah Nu Sumber Agung. Then, there is no difference in English learning outcomes between grade 4 students of Madrasah Ibtidaiyah $\mathrm{Nu}$ Sumber Agung with high self-confidence and low selfconfidence. And the last, there is no interaction of methods with selfconfidence on learning achievement in English.
\end{abstract}

Keywords: Conversation Method, Self-Confidence, Learning Achievement

\section{INTRODUCTION}

English is very important in the world of education at this time (Hyland, 2013). In several countries including Indonesia, elementary schools (Madrasah Ibtidaiyah) have included English in the compulsory curriculum (Sukarno, 2008). Teaching and learning English activities in elementary school are important because children at this age have the ability to remember and learn things easily. There are two things that constitute the competence of English itself, namely linguistic competence and linguistic ability (Brown, 2001). The Ministry of Research, Technology and Higher Education of the Republic of Indonesia (Kemenristek Dikti RI) (2006) states that English lessons at the elementary level are expected to complete certain competencies after having learning experience and going through the English learning process. Elementary students are expected to be able to apply knowledge both theoretically and practically. According to Yamin (2017), the English learning method is the key in learning. If the teacher is not able to find the right learning method, then learning will tend to be boring. As a result, students will tend to be bored and do not like English lessons. 
English proficiency in Indonesia is ranked 74th out of 100 countries recorded in the English Profiency Index (EF EPI) in 2020. This ranking can illustrate that English proficiency in Indonesia is still quite low. Seeing this fact, English learning should be further improved (Zulkifli, 2015). One of the ways to hone English in students is by reading. The habit of reading in individuals is a manifestation of the individual's high reading interest (Saepudin \& Mentari, 2016), but reading alone is not enough because learning is needed while having conversations or also called learning by conversation. Some problems in the teaching and learning process are still often found, especially because the learning process is not interesting. Many sources state that the management of the English teaching and learning process is the main problem that causes many problems that are connected to each other (Yunita \& Pertiwi, 2017).

Madrasah Ibtidaiyah $\mathrm{Nu}$ Sumber Agung is an elementary school in the city of OKU Timur that continues to strive to develop English language skills for its students. Evidently, students' English learning outcomes have not been fully satisfactory. Students still tend to be afraid and seem to avoid English lessons. There is also a habit of students refusing each other due to lack of confidence when the teacher asks to explain related to English. While in the current era really need speed and acceleration in speaking English. One of the causes of this is because the learning methods used still tend to be monotonous and use the classic way. Based on the description of the background of the problem, the authors took 3 purposes for this research, namely: 1.) Knowing the differences in English learning achievement between learning by conversation methods and conventional methods for fourth grade students of Madrasah Ibtidaiyah $\mathrm{Nu}$ Sumber Agung; 2.) Knowing the difference in English learning achievement between high selfconfidence and low self-confidence of the fourth grade students of Madrasah Ibtidaiyah $\mathrm{Nu}$ Sumber Agung; and 3.) Knowing the interaction of the learning by conversation method with self-confidence on the achievement of learning English

\section{METHOD}

This research was conducted at Madrasah Ibtidaiyah Nu Sumber Agung, whose address is at Jl. Depati Agung Desa Sumber Agung, Buay Madang, Oku Timur, Indonesia. This study uses a quantitative approach, namely research activities by prioritizing data collection in the form of numbers, then the numbers are analyzed using two-way Annava statistics (Two Way Anova) SPSS version 24 (Bazeley, 2013; Creswell, 2014; Johnson \& Onwuegbuzie, 2004; Lafrenière et al., 2018; Solikhah \& Herlisya, 2021).

This research was carried out using an experimental research design model with 2 (two) groups of subjects taken from Madrasah Ibtidaiyah $\mathrm{Nu}$ Sumber Agung, namely grades 4A and $4 \mathrm{~B}$. The hypothesis that will be tested is true, namely about the differences in the use of the learning by conversation method on self-confidence and student learning outcomes, with using a factorial experimental design $(2 \times 2)$ which can be seen in Table 1 . The sample of this study consisted of 2 classes, each 1 experimental class and 1 control class, while the total number of individuals was 71 students. Before discussing the learning outcomes test, first discuss the results of the validity test and the reliability test of the learning outcome test as a research instrument. Experiments carried out in this study were using a factorial design $(2 \times 2)$. 
Table 1. Factorial Research Design 2x2

\begin{tabular}{cccc}
\hline & Method & Conventional Method & $\begin{array}{c}\text { Learning by } \\
\text { Conversation Method }\end{array}$ \\
\hline Variable Moderator & High & Y11 & Y12 \\
& Low & Y12 & Y22 \\
\hline
\end{tabular}

Notes:

Y11 $=$ High self-confidence learning outcomes with conventional methods

Y12 = High self-confidence learning outcomes with learning by conversation

Y21 = Low self-confidence learning outcomes with conventional methods

Y22 = Low self-confidence learning outcomes with learning by conversation

The subject of this research is the fourth grade students of Madrasah Ibtidaiyah $\mathrm{Nu}$ Sumber Agung Class 4A and 4B. Each one is taken 1 (one) class as the experimental class and 1 (one) class as the control class. The sampling technique used is random sampling, i.e. the selection of samples is not based on individuals, but rather based on groups, regions, or groups of subjects who naturally gather together (Sukardi, 2004). The sample in this study can be seen in Table 2.

Table 2. Research Sample

\begin{tabular}{cccc}
\hline School & Class & Students & Groups \\
\hline Madrasah Ibtidaiyah Nu & IV A & 35 & Experimental Class \\
Sumber Agung & & & Control Class \\
& IV B & 36 & \\
Total of Students & & 71 & \\
\hline
\end{tabular}

According to Arikunto (2009), the variable is the object of research or the point of attention. In order to avoid errors in the interpretation of variables, it is necessary to define operational research variables as follows:

The independent variable is the variable that precedes or influences. In this study, the independent variable studied was the use of the learning by conversation method.

The dependent variable is a variable that is a result of or depends on the variable that precedes it. In this study, the dependent variable studied was learning achievement.

The moderator variable is self-confidence which is one of the factors that can improve the quality of learning, because students will study seriously when they have high selfconfidence. The treatment of activities for the two groups is of course adjusted to the research design model above. Group I, which is from Class A, is a class that is given treatment in the form of applying the learning by conversation method. Meanwhile, group II comes from Class $\mathrm{B}$ which is the control class using conventional (usual) teaching methods.

The implementation of experimental treatment for Group I and Group II is explained as follows: Group I (subjects who are given learning are accompanied by Learning by Conversation). Prior to treatment, students were tested with pretest questions both related to material and self-confidence. This group is given material that is summarized in the form of a conversation for each chapter. This conversation contains about the subject matter. Then students are asked to practice this conversation directly 
with friends by using intonation and expression. This treatment is carried out in class from February to early March 2020 with a total of 4 units of material covered. After completing the 4 units of material, a post-test was carried out both related to achievement and self-confidence. Group II (subjects who are given learning as usual, namely the conventional method). The treatment starts from February to early March 2020. As usual, the material is given in class using the usual lecture method. After finishing the material, a post-test was carried out related to learning achievement and self-confidence.

\section{FINDINGS AND DISCUSSION}

\section{Results}

Research instrument is a tool used to retrieve data or information. The truth of the data or information taken depends on the correctness of the instrument used. Thus the determination, arrangement, and interference of instruments is an important part of research management.

\section{Results}

This self-confidence questionnaire instrument was prepared using the Linkert scale in the form of an objective questionnaire with a total of 20 questions, and five alternative answers. The answer scores of the five alternatives move from the highest score to the lowest score. The five value scales can be seen in Table 3 .

Table 3. Score of Questionnaire Confidence

\begin{tabular}{clc}
\hline No. & Criteria & Score \\
\hline 1 & SS (Do Agree) & 5 \\
2 & S (Agree) & 4 \\
3 & R (Doubt) & 3 \\
4 & TS (Dis Agree) & 2 \\
5 & STS (Really Disagree) & 1 \\
\hline
\end{tabular}

The highest score that will be obtained in the questionnaire is $5 \times 20=100$, while the lowest possible score is $1 \times 20=20$. The boundary between high self-confidence and low selfconfidence is determined by: Limit Score $=$ (Highest score + Lowest score $) / 2$, so the Limit Score $=(100+20) / 2=60$. Therefore, the limit score determined is 60 . The total scores obtained by students are grouped into high self-confidence and low self-confidence with the following limitations: High self-confidence $=61-100$, Low self-confidence $=20-60$.

\section{Test}

In this study, the learning achievement test that will be used is a daily test made by the teacher which refers to basic competencies and competency standards in the form of objective tests. The total number of test items is 20 test items, each item answered correctly is given a score of 5, thus the maximum score that can be achieved is 100 in 60 minutes. The materials tested include: Unit 1: Family Circles, Unit 2: Stories, Unit 3: Day and Night, Unit 4: Homes. At the level of data analysis, there are three steps taken, 
namely: data description, test requirements analysis, and hypothesis testing. For the accuracy of the analysis using the help of the SPSS program.

Table 4. Frequency of Learning Achievment in English (Pretest)

\begin{tabular}{cccccc}
\hline & & Frequency & Percent & Valid Percent & Cumulative Percent \\
\hline \multirow{6}{*}{ Valid } & 50 & 2 & 5.6 & 5.6 & 5.6 \\
& 55 & 3 & 8.3 & 8.3 & 13.9 \\
& 60 & 5 & 13.9 & 13.9 & 27.8 \\
& 65 & 9 & 25.0 & 25.0 & 52.8 \\
& 70 & 10 & 27.8 & 27.8 & 80.6 \\
& 75 & 6 & 16.7 & 16.7 & 97.2 \\
& 80 & 1 & 2.8 & 2.8 & 100.0 \\
\hline
\end{tabular}

Table 5. Frequency of Learning Achievement in English (Posttest)

\begin{tabular}{cccccc}
\hline & & Frequency & Percent & Valid Percent & Cumulative Percent \\
\hline \multirow{6}{*}{ Valid } & 65 & 1 & 2.8 & 2.8 & 2.8 \\
& 70 & 2 & 5.6 & 5.6 & 8.3 \\
& 75 & 7 & 19.4 & 19.4 & 27.8 \\
& 80 & 13 & 36.1 & 36.1 & 63.9 \\
& 85 & 9 & 25.0 & 25.0 & 88.9 \\
& 90 & 3 & 8.3 & 8.3 & 97.2 \\
& 95 & 1 & 2.8 & 2.8 & 100.0 \\
\hline
\end{tabular}

Table 6. Frequency of Learning Achievement in English (Pretest) with Method Learning by Conversation

\begin{tabular}{|c|c|c|c|c|c|}
\hline & & Frequency & Percent & Valid Percent & Cumulative Percent \\
\hline \multirow{8}{*}{ Valid } & 50 & 1 & 2.8 & 2.9 & 2.9 \\
\hline & 55 & 10 & 27.8 & 28.6 & 31.4 \\
\hline & 60 & 8 & 22.2 & 22.9 & 54.3 \\
\hline & 65 & 8 & 22.2 & 22.9 & 77.1 \\
\hline & 70 & 6 & 16.7 & 17.1 & 94.3 \\
\hline & 75 & 1 & 2.8 & 2.9 & 97.1 \\
\hline & 80 & 1 & 2.8 & 2.9 & 100.0 \\
\hline & Total & 35 & 97.2 & 100.0 & \\
\hline Missing & System & 1 & 2.8 & & \\
\hline
\end{tabular}

Table 7. Frequency of Learning Achievement in English (Posttest) with Method Learning by Conversation

\begin{tabular}{cccccc}
\hline & & Frequency & Percent & Valid Percent & Cumulative Percent \\
\hline \multirow{4}{*}{ Valid } & 85 & 8 & 22.2 & 22.9 & 22.9 \\
& 90 & 13 & 36.1 & 37.1 & 60.0 \\
& 95 & 6 & 16.7 & 17.1 & 77.1 \\
\multirow{4}{*}{ Missing } & 100 & 8 & 22.2 & 22.9 & 100.0 \\
& Total & 35 & 97.2 & 100.0 & \\
\hline & System & 1 & 2.8 & & \\
\hline
\end{tabular}


Table 8. Frequency of Confidence (Pretest)

\begin{tabular}{cccccc}
\hline & Frequency & Percent & Valid Percent & Cumulative Percent \\
\hline \multirow{6}{*}{ Valid } & 3 & 8.3 & 8.3 & 8.3 \\
& 56 & 5 & 13.9 & 13.9 & 22.2 \\
& 58 & 2 & 5.6 & 5.6 & 27.8 \\
& 60 & 3 & 8.3 & 8.3 & 36.1 \\
& 65 & 5 & 13.9 & 13.9 & 50.0 \\
& 66 & 6 & 16.7 & 16.7 & 66.7 \\
& 68 & 3 & 8.3 & 8.3 & 75.0 \\
& 70 & 5 & 13.9 & 13.9 & 88.9 \\
& 75 & 2 & 5.6 & 5.6 & 94.4 \\
& 77 & 2 & 5.6 & 5.6 & 100.0 \\
\hline
\end{tabular}

Table 9. Frequency of Confidence (Posttest)

\begin{tabular}{cccccc}
\hline & Frequency & Percent & Valid Percent & Cumulative Percent \\
\hline \multirow{6}{*}{ Valid } & 1 & 2.8 & 2.8 & 2.8 \\
& 68 & 1 & 2.8 & 2.8 & 5.6 \\
& 70 & 6 & 16.7 & 16.7 & 22.2 \\
& 75 & 6 & 16.7 & 16.7 & 38.9 \\
& 76 & 8 & 22.2 & 22.2 & 61.1 \\
& 77 & 3 & 8.3 & 8.3 & 69.4 \\
& 78 & 6 & 16.7 & 16.7 & 86.1 \\
& 80 & 5 & 13.9 & 13.9 & 100.0 \\
\hline
\end{tabular}

Table 10. Frequency of Confidence (Pretest) with Method Learning by Conversation

\begin{tabular}{|c|c|c|c|c|c|}
\hline & & Frequency & Percent & Valid Percent & Cumulative Percent \\
\hline & 56 & 2 & 5.6 & 5.7 & 5.7 \\
\hline & 57 & 1 & 2.8 & 2.9 & 8.6 \\
\hline & 58 & 2 & 5.6 & 5.7 & 14.3 \\
\hline & 60 & 5 & 13.9 & 14.3 & 28.6 \\
\hline & 62 & 2 & 5.6 & 5.7 & 34.3 \\
\hline \multirow[t]{6}{*}{ Valid } & 64 & 3 & 8.3 & 8.6 & 42.9 \\
\hline & 65 & 3 & 8.3 & 8.6 & 51.4 \\
\hline & 66 & 6 & 16.7 & 17.1 & 68.6 \\
\hline & 68 & 5 & 13.9 & 14.3 & 82.9 \\
\hline & 70 & 6 & 16.7 & 17.1 & 100.0 \\
\hline & Total & 35 & 97.2 & 100.0 & \\
\hline \multirow[t]{2}{*}{ Missing } & System & 1 & 2.8 & & \\
\hline & Total & 36 & 100.0 & & \\
\hline
\end{tabular}

Table 11. Frequency of Confidence (Posttes) with Method Learning by Conversation

\begin{tabular}{cccccc}
\hline & & Frequency & Percent & Valid Percent & Cumulative Percent \\
\hline & 84 & 4 & 11.1 & 11.4 & 11.4 \\
& 85 & 5 & 13.9 & 14.3 & 25.7 \\
& 86 & 10 & 27.8 & 28.6 & 54.3 \\
Valid & 87 & 1 & 2.8 & 2.9 & 57.1 \\
& 88 & 3 & 8.3 & 8.6 & 65.7 \\
& 89 & 2 & 5.6 & 5.7 & 71.4
\end{tabular}


The Effect of Applying...

\begin{tabular}{cccccc} 
& 90 & 7 & 19.4 & 20.0 & 91.4 \\
& 92 & 3 & 8.3 & 8.6 & 100.0 \\
\multirow{4}{*}{ Missing } & Total & 35 & 97.2 & 100.0 & \\
\hline & System & 1 & 2.8 & & \\
\hline
\end{tabular}

\section{Normality Test}

The normality test was used to determine whether the learning achievement data obtained and analyzed came from a normal distribution. The normality test in this study was carried out using the Kolmogorof-Smirnov technique. Based on Table 12, it is obtained data that the results of the normality test of learning outcomes data for all classes show a KMZ value of 0.2 with a significance level above $0.05(5 \%)$, so this result means rejecting the assumption that the data distribution is not normal. So, it can be concluded that the results of the normality test show that the distribution of learning outcomes data is normal (Ho is accepted).

Table 12. Result of Normality Test

\begin{tabular}{llr}
\hline & Achievement of Learning & 71 \\
Normal Parameters ${ }^{\mathrm{a}, \mathrm{b}}$ & & 86.1971 \\
& Mean & .32630090 \\
Most Extreme Differences & Std. Deviation & .073 \\
& Absolute & .073 \\
& Positive & -.057 \\
Test Statistic & Negative & .073 \\
Asymp. Sig. (2-tailed) & & $.200^{\mathrm{c}, \mathrm{d}}$ \\
\hline
\end{tabular}

\section{Homogeneity Test}

The homogeneity of variance test is intended to test the homogeneity (similarity) of the variance of the learning outcomes data obtained and analyzed from the entire research sample group. The homogeneity of variance test was carried out by the lavender test technique (Lavene's Test). Based on the results of the Lavene's test analysis, it is known that the value of Fcount is 0.6 with a significance level (sign) of $=0.7$. Based on the magnitude of the coefficient of significance level produced, which is greater $(>)$ than $0.05(5 \%)$, then the assumption that there is no difference in variance between sample groups can be accepted. The results of the homogeneity test can be seen in Table 13 .

Table 13. Result of Homogenity Test

\begin{tabular}{cccc}
\hline \multicolumn{4}{c}{ Dependent Variable: Learning Outcomes } \\
\hline $\mathrm{F}$ & $\mathrm{df1}$ & $\mathrm{df} 2$ & Sig. \\
.600 & 5 & 136 & .700 \\
\hline
\end{tabular}

\section{Hypothesis testing}

Analysis of variance (Anava) 2 lines was conducted to examine the joint effect of learning and self-confidence on learning achievement in English. The results of hypothesis testing in this study can be seen in Table 14. 
Table 14. Result of Hypotesis Test

\begin{tabular}{lccccc}
\hline \multicolumn{1}{c}{ Source } & Type III Sum of Squares & Df & Mean Square & F & Sig. \\
\hline Corrected Model & $19933.370^{\mathrm{a}}$ & 5 & 3.986 .674 & 93.687 & .000 \\
Intercept & 481.857 .927 & 1 & 481.857 .927 & 11.323 .672 & .000 \\
Class & 17.253 .326 & 3 & 5.751 .109 & 135.151 & .000 \\
Confidence & 60.492 & 1 & 60.492 & 4.422 & .235 \\
Class * Confidence & 26.585 & 1 & 26.585 & 3.625 & .431 \\
Error & 5.787 .228 & 136 & 42.553 & & \\
Total & 828.225 .000 & 142 & & & \\
Corrected Total & 25.720 .599 & 141 & & & \\
a. R Squared $=.775$ (Adjusted R Squared =.767) & & & & \\
\hline
\end{tabular}

\section{Discussion}

This research was conducted at Madrasah Ibtidaiyah Nu Sumber Agung, whose address is at J1. Depati Agung Desa Sumber Agung Buay Madang Oku Timur, Indonesia. This study uses a quantitative approach. This research was carried out using an experimental research design model with 2 (two) groups of subjects taken from Madrasah Ibtidaiyah $\mathrm{Nu}$ Sumber Agung, namely grades $4 \mathrm{~A}$ and $4 \mathrm{~B}$. The sample of this study consisted of 2 classes, each 1 experimental class and 1 control class, while the total number of individuals was 71 students. Based on the results obtained in this study, it can be concluded that: 1.) There are differences in learning achievement, especially in English subjects, between learning methods using learning by conversation and conventional learning methods for grade IV students of Madrasah Ibtidaiyah $\mathrm{Nu}$ Sumber Agung; 2.) There is no difference in learning achievement, especially in English subjects, between high self-confidence and low self-confidence for fourth grade students of Madrasah Ibtidaiyah $\mathrm{Nu}$ Sumber Agung; and 3.) There is no interaction between methods and self-confidence on learning achievement, especially in English for grade IV students of Madrasah Ibtidaiyah Nu Sumber Agung.

\section{CONCLUSION}

This research was conducted at Madrasah Ibtidaiyah Nu Sumber Agung, whose address is at J1. Depati Agung Desa Sumber Agung Buay Madang Oku Timur, Indonesia. This study uses a quantitative approach. This research was carried out using an experimental research design model with 2 (two) groups of subjects taken from Madrasah Ibtidaiyah Nu Sumber Agung, namely grades 4A and 4B. The sample of this study consisted of 2 classes, each 1 experimental class and 1 control class, while the total number of individuals was 71 students. Based on the results obtained in this study, it can be concluded that: 1.) There are differences in learning achievement, especially in English subjects, between learning methods using learning by conversation and conventional learning methods for grade IV students of Madrasah Ibtidaiyah $\mathrm{Nu}$ Sumber Agung; 2.) There is no difference in learning achievement, especially in English subjects, between high self-confidence and low self-confidence for fourth grade students of Madrasah Ibtidaiyah $\mathrm{Nu}$ Sumber Agung; and 3.) There is no interaction between methods and self-confidence on learning achievement, especially in English for grade IV students of Madrasah Ibtidaiyah Nu Sumber Agung 


\section{REFERENCES}

Amar, A., \& Rufi'i, R. (2009). Pengaruh eksperient learning model dan gaya belajar terhadap prestasi belajar fisika siswa SMPN 2 Jatirogo dan SMPN 1 Kenduruan Tuban tahun pelajaran 2008/2009. Improving Teachers Professionalism to Face the Global Education Challanges, 89-102. Retrieved from https://karyailmiah.unipasby.ac.id/wp-content/uploads/2018/04/

PROCEEDINGS-ICETA-1_2009.pdf\#page $=93$

Arikunto, S. (2009). Manajemen Pendidikan. Jakarta: Rineka Cipta.

Asiyah, A., Walid, A., \& Kusumah, R. G. T. (2019). Pengaruh rasa percaya diri terhadap motivasi berprestasi siswa pada mata pelajaran IPA. Jurnal Pendidikan Dan Kebudayaan, 9(3), 217- 226. https://doi.org/10.24246/j.js.2019.v9.i3.p217-226

Bazeley, P. (2013). Qualitative Data Analysis (J. Seaman (ed.); 1st ed.). SAGE Publication. https://doi.org/10.1080/14780887.2014.992750.

Brown, H. D. (2001). Principles oflanguage learning and teaching. New York: Longman.

Creswell, J. (2014). Research design: Qualitative, Quantitative, and Mixed Methods Approaches (V. Knight (ed.); Fourth Edi). SAGE Publication. https://doi.org/10.4135/9781849208956.

Fatmala, L., Yusmansyah, Y., \& Andrianto, R. E. (2018). Hubungan antara kepercayaan diri dengan prestasi belajar siswa kelas VIII. Alibkin: Jurnal Bimbingan Konseling, 6(3).

Hyland, K. (2013). Writing in the university: education, knowledge and reputation. $\begin{array}{lllll}\text { Language } & \text { Teaching, } & 46(1), & 53 & -\end{array}$ https://doi.org/10.1017/S0261444811000036

Johnson, B., \& Onwuegbuzie, A. J. (2004). Mixed Methods Research: A research Paradigm Whose Time Has Come. Educational Researcher, 33(7), 14-26. https://doi.org/10.3102/0013189X033007014.

Kementerian Riset dan Teknolgi Pendidikan Tinggi Republik Indonesia. (2006). Dokumen standarkompetensi guru kelas SD-MI lulusan S1 (SKKG-SD/MI). Jakarta: Kementerian Pendidikan dan Kebudayaan.

Lafrenière, A., Lortie-Lussier, M., Dale, A., Robidoux, R., \& De Koninck, J. (2018). Autobiographical memory sources of threats in dreams. Consciousness and Cognition, 58(October 2017), 124-135. https://doi.org/10.1016/j.concog.2017.10.017

Listiyani, L. (2019). Hubungan antara dukungan sosial orang tua dengan kepercayaan diri. Journal for Lesson and Learning Studies, 2(1), 10-20. https://doi.org/10.23887/jlls.v2i1.17315

Mardiyah, M., Mustaji, M., \& Sitompul, N. C. (2018). Meningkatkan keterampilan writing of narrative text dengan menggunakan teaching materials. Edcomtech : Jurnal Kajian Teknologi Pendidikan, 4(2), 89-95. https://doi.org/10.17977/um039v4i22019p089

Riyani, G. S., \& Rufi'i, R. (2019). Pengaruh pendekatan kontekstual, konvensional dan motivasi belajar terhadap prestasi belajar bahasa Indonesia siswa kelas VIII SMP Negeri 6 dan SMP Negeri 12 Surabaya. Improving Teachers Professionalism to Face the Global Education Challanges, 303-317. Retrieved from 
https://karyailmiah.unipasby.ac.id/wp-

content/uploads/2018/04/PROCEEDINGS-ICETA-1_2009.pdf\#page=93

Saepudin, A., \& Mentari, B. N. (2016). Menumbuhkan minat baca masyarakat melalui taman bacaan masyarakat berbasis teknologi informasi. Kwangsan: Jurnal Teknologi Pendidikan, 4(1), 43-54. https://doi.org/10.31800/jtp.kw.v4n1.p43$-54$

Solikhah, N. A., \& Herlisya, D. (2021). Ability to write a Reader's Letter About the School Environment in 03 Lumbir State Junior High School. Joumal Corner of Education, Linguistics, and Literature (JCELL), 1(1), 21-27. https://doi.org/https://doi.org/10.54012/jcell.v1i1.8

Suhud, S., Sitompul, N. C., \& Sugito, S. (2020). Pengembangan bahan ajar berbasis karakter di abad- 21 pelajaran bahasa Indonesia kelas XI. JURNAL EDUCATION AND DEVELOPMENT, 8(2),

417.

Sukardi, S. (2004). Metodologi penelitian: Kompetensi dan praktiknya. Jakarta: Bumi Aksara. Sukarno, S. (2008). Teaching English to Young Learners and Factors to Consider in Designing The Materials. Jurnal Ekonomi Dan Pendidikan, 5(1). https://doi.org/10.21831/jep.v5i1.603

Wardani, M. A. P., Rufi'i, R., \& Harwanto, H. (2020). Pengaruh penerapan strategi pembelajaran berbasis ICT terhadap pencapaian hasil belajar sistem komputer siswa kelas X SMK. Faktor: Jurnal Ilmiah Kependidikan, 7(2), 99-106. https://doi.org/10.30998/fjik.v7i2.3459

Yamin, M. (2017). Metode pembelajaran bahasa Inggris di tingkat DAS. Pesona Dasar (JurnalPendidikan Dasar Dan $\quad$ Humaniora), $\quad 1(5), \quad 82-$ 97.

Yunita, R., \& Pertiwi, N. (2017). Developing English program for elementary school teacher education students. The International Journal of Learning, 3(3), 176-183. https://doi.org/10.18178/IJLT.3.3.176-183

Zulkifli, N. A. (2015). Meningkatkan kemampuan bahasa Inggris siswa dengan menggunakan running dictation melalui materi agama di SD IT Al-Fittiyah Pekanbaru. Kutubkhanah, 17(2), 175-197. 